\title{
Commentary from Established Scholars: A man is not a tree
}

\author{
Dr. Farid M. Shomali \\ Emeritus Doctor of Architecture (Retired) \\ fshomali@hotmail.co.uk \\ Amman 11953 - Jordan
}

\begin{abstract}
There is something wrong, an architect meditating on current religion debates and human behaviors. This study will fill a big gap that will show its effects in the future in all religion debates, moreover, if its principles where applied then a huge relief to humanity will shine in the nearest future and for all generations to come. No coauthors, institutional or influencers' interventions
\end{abstract}

Key Words: Religion Debates, Biblical faith, Limitations, Second Commandment, Atheism, Cremation, burial, King James

DOI: $10.7176 /$ RHSS/10-12-08

Publication date:June 30th 2020

Introduction: If you are in the biblical faith; then you are waiting for the third day and more for resurrection. Can this be possible with cremation, burial underground and inside walls closed with cement before the third day and after? If you practiced that then you are either from the atheist community, alternatively, you are from other current communities including biblical once who bury the dead and in this, you are all equal

Discussion: How do you know if we have to bury the dead or not as an atheist? Do you as an atheist do stupid things without knowing the consequences? Is there an experiment that you did in this regard? Do you as atheist know the truth to say whether to bury the dead or not? In addition, if you try to fight burial, cremation and any other similar ideology before you die as an atheist, knowing that this is the truth, then are you a liar when you say you are an atheist! Should we wait for the third day or more for faithful to the biblical faith to know the validity of God's words? Do you have a voice to reject the burial idea if you knew that it is the truth! To conclude, burial and cremation are methods of keeping a person afraid all of his lifetime practiced by atheist and other religions including Biblical once. If your mother, son or daughter dies, do you put them underground the next days, if you take care of your child, his appearance and health all your lifetime then where is your mind when you put him underground the next days when he dies - and here we can see the failure!

anybody can feel from god's plan and scriptures that cremation and burial by any means prohibited, 100\% terror act and disrespectful. Thus must be announced to all the people of the world. You must know the unnecessary fear that your generations might went through all their lifetime from attending such act, maybe without consciousness. You all might have noticed it, and nobody can ever comprehend the meaning or reason for it unless he thinks something is wrong with the people practicing it. The message must be spread, and hope others can do it by their means; the best thing is to follow this rule to the end. Case closed, if you are an atheist you can never know if we have to bury the dead or not, so atheism failed completely, burring is stupid and it must be the $11^{\text {th }}$ commandment if not the second one.

Kindly study the picture below:

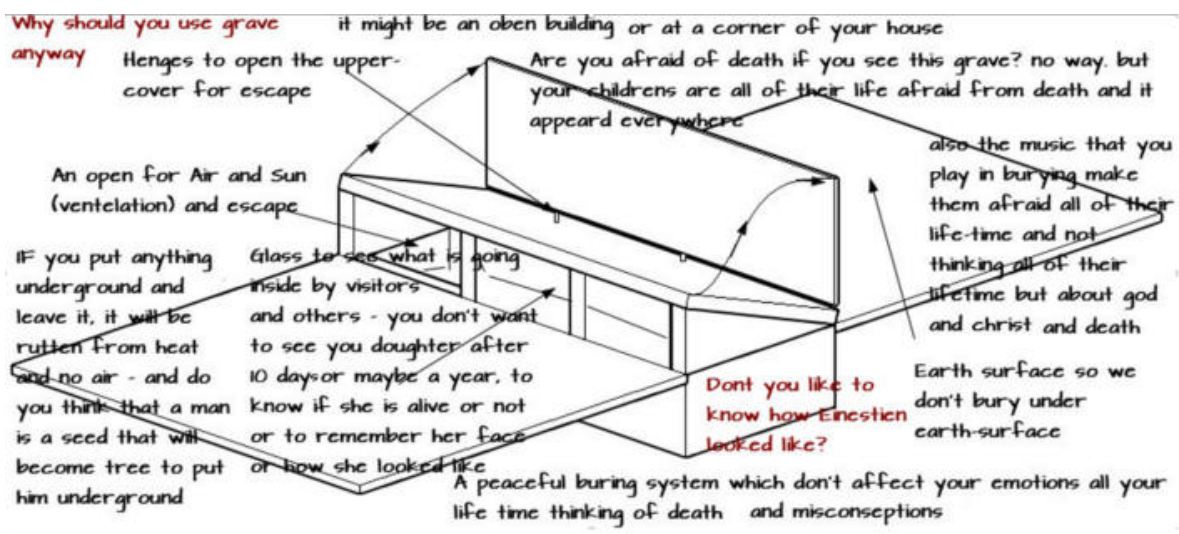

This illustration; drawn by the Author, demands architects to find better solutions and designs for ,not a safe kind 
of, graves or leaving grave limitations at all since you don't put bodies in the wild; towards using buildings containing our bodies. Prohibited if done in a very secure way by any cost; in secure I mean: as in refrigerators, inside walls, inside boxes, inside safes, inside walls and underground or in a way that does not provides clear exit, access, ventilation, air, sun indirect exposure, light infiltration, clean environment and hygienic standards and complete visual access to the body. Showing emphasis on the effects of what you see, hear and experience on your ideas and habits. Conflicts produced by not following those rules, must be, prohibited, observed and fixed. Since if done or observed by only one person and the idea spread again will put people backward hundreds of years and more. Meaning that this habit must be: learned, informed, completely believed and reasoned as a commandment of God since reason says it is so. What just brought this subject up in the first place? What brought the subject up is the unnecessary fear and uncertainty habits that many may went through in their lifetime without conscious, you can notice that in half of you-tube videos talking about religion. I think this is the reason for that unnecessary fear, uncertainty habits and future regret. What is the solution then? In life, my-self, others, and I believe including yourself have abandoned many false ideas then went on with life forward and we have come a long way. What to hate are false ideas and uncertainty habits, not persons. Cremation and burial are false ideas and uncertainty habits that will stick with you all of your lifetime. Dust-to-dust (Genesis 3:19) must be examined since the New Testament rejected it. Do you take everything for granted!

(See previous picture) if a body buried in a grave, as in the attached picture you are not afraid about the dead and you are satisfied you did not do something wrong. Wait a minute, you might even think that you did something wrong putting the body in the wild, and you have to put him in a nice ventilated sunny building, Instead of the grave limitations, size and misery. To visit the dead maybe after 10 days or more, to be free from the fear of death and thinking about it all your life as you all do now. However, if one meter under the ground then you are afraid all of your lifetimes, ashamed all your lifetime thinking about it! As what is going on nowadays with many people who regretted putting their father, mother or relatives underground or did not bother to care about the consequences or giving it one thought. Not to forget to mention also the people who declare believing in resurrection and after life on earth, but do the opposite of what logic and reality implies to solve the situation. Strange how did not any person or human being in cemetery I visited here in Jordan; didn't thought of putting a glass on any of the graves or to make the body easily accessible. Did not reason, but putting it in the wild or restricted it to the stupid box. Have not thought about the way out proposed in this paper Then I figured it out; they say they know everything while they do not know everything They are deceived about the matter of death. They say they believe in resurrection but they don't, looking at us from above deceiving people while they are the wrong who did whatever they liked then bury.

Conclusions: This paper represents the author believes about the subject matter, and the author believes about what must be done to solve this issue. We all must once, and for all. Immediately from this moment on, stop these two false ideas and go on. If you see these two acts done then do something about it, and inform others; for you should never think about it in the first place, burial and cremation are false ideas and heresies; rejecting burial and cremation even if the body dissolves in front of your eyes is the solution. Because it is not your problem, it is God's problem; stopping thinking about it to go forward is the way out. A man is not a tree, nor a seed to put him under the ground. Man must always be above the ground; if you saw dissolved body then leave it alone, since it is not your problem and you cannot reason what to do about it without using the above-mentioned standards. To justify your reason or come with wrong reasons and fantasy ideas about it does have consequences and you saw it. The bible said that a man comes to life after 3 days if he believed in its words, in three days and more, so burial and cremation are prohibited; false ideas, uncertainty habits and future regrets.

References: Genesis 3:19, Holy Bible: King James Version 